\title{
Related Issues Study to the Marxist Youth under the Communication Language Environment
}

\author{
Xueping XU \\ Luohe Medical College \\ Luohe,462000 China
}

\begin{abstract}
Marxism youth is the youth of Marxism and Marxism of youth's dialectical unity. Summarizing the basic experience of Marxist youth's understanding premise, theoretical premise and spread process, and its communication body, communication content, communication methods and process, characteristic and need of communication objective, so the Swell " $5 W$ " transmission mode which emphasizing the communicators control role of thinking has became the first choice of the spread of contemporary young Marxism. And from the angel of communication subject popularization, communication object more qualitative, communication contents modernization, communication methods diversification, communication effect control, this paper put on training opinion leaders, grasping the audience characteristics, innovating discourse system, smoothing feedback, rich spread media and other strategy about the spread of Marxism youth in China.
\end{abstract}

Keywords- Communication; Marxism youth-oriented; Strategic Thinking

\section{INTRODUCTION}

Marxism youth is an important part of the popularization of Marxism, it is an important force to boost the popularization of Marxism, and it is directly related to youth development, related to Chinese characteristics socialism scientific development, related to the rejuvenation of the Chinese nation, it is an issue that affect the rise and fall of the country and nation.

\section{CONNOTATION OF MARXISM YOUTH}

\section{A. The basic connotation of Marxism Youth}

Marxism youth-oriented, refers to Marxism's basic principles, basic idea popularized, specific, visualized, and conformation to the characteristics and the law of young people, for the majority of young people to understand, accept, master and bear in mind in order to effectively arm youth, it has became the ideological agenda and action guide of youth and develop youth's creative talents and wisdom, it is closer to the era, life, and the youth, always keep the innovative spirit, and always maintain the vitality and creativity of innovation theory that dialectical unity of the youth of Marxism and Marxism of the Youth. 'Youth' of
Marxism is through contact with the youth, get the good character of young people's thinking, innovation, creation, and to be converted to theory quality of Marxism's progressive and innovative, dialectical development, so that the life of Marxism tree evergreen. Marxism of youth means use thinking with fresh, full of period features of Marxism to arm youth, use features and methods that youth easy to accept, so that Marxism becomes the ideological theory and action program guide of young people, with Marxism leading youth thinking quality and ways of thinking, and internalized into their world outlook and methodology, externalized into conscious practice, guiding young people's innovation practice process.

\section{B. Basic Historical Experience of Marxism Youth}

Understanding Premise: winning the youth is winning future and hope. From the development process of the Communist Party of China, the youth is always an important component of the ruling class foundation of the Party; the youth is an important promoter and inheritor, and also the focus of contention hostile forces. Pay great attention of Marxist youth is an important way to develop Marxism and Marxist culture, but also the experience and an important tradition of the Communist Party of China. Lu Shizhen thinks that we should start to see the spread of youth development perspective of contemporary Chinese Marxism. Countries in the world have paid attention to youth development, and youth development has become an important indicator of the extent of a country's economic and social development level.

Theoretical basis: Marxism's Chinese, modernization, popularization is theoretical basis and practical motivation of Marxist youth. The combination of theoretical and practical knowledge to the referred party building height, cleared the theoretical origins of the Communist Party of China Marxist theory of education in the history of the development dimension, to guide and promote the Marxist youth of great significance and value.

Propagation: influence spread. Marxist indoctrination and acceptance is an important way to Marxism youth and internalization process, and promoting theoretical innovation is the inevitable outcome and target of youth of Marxism.

Marxism of Youth is the unity of internalization and externalization, of social indoctrination within individual 
two-pronged approach, of the cycle of instill a mind to accept a theory to guide practice. The first is to instill young people outside Marxist theory making the majority of young people study, understand, believe, and use Marxism. Here with "indoctrination" concept, in the broad sense, that the specific input channels and the way is very complex and diverse, it is according to the youth own ideas and thinking characteristics to accept and understand Marxism, combined with their actions and seek practical the point is to learn and master the youth on the basis of Marxism on the inside of the Marxist theory of their own thinking system, and specifically to guide practice and action. Youth of Marxism, firstly, young person is important to promote the spread of Marxism. Secondly, young people are an important heritage and innovator of Marxism. Young people are the most active and most innovative social group, and practices and behavior of young Marxist theoretical innovation constantly enrich and improve the theoretical system of Marxism, as Marxism continued injection of fresh content. Training young leaders is an important way of Marxism Youth. Marxism successfully led of the youth growth is the most powerful prove of their theory.

\section{SPREAD MODE SELECTION OF YOUTH-ORIENTED MARXISM}

\section{A. Features of Youth-oriented Marxism under Communication Context}

Communication body: Follow the law and the formation of the psychological development of young Marxism ideology; we can effectively achieve the task to lead the contemporary youth ideological age and growth of services.

Communication content: Marxism is the content of the spread of Marxism in youth, is a systematic, complete scientific system. Marxism is the holistic nature of the content properties and the inherent characteristic of Marxism, Marxism is an objective law of development, is to uphold the fundamental principles of Marxism.

Communication channels and methods: Marxism current channels of communication among young people are highly concentrated, mainly one-way communication organizations and institutions, with a high degree of consistency. The current spread of Marxism in the youth of the main ways to educate young people in a state of passive acceptance, bidirectional feedback, equal dialogue, exchange of ideas and views collide serious lack plaque.

Communication objective: Marxist youth of the ultimate goal is to make contemporary youth in the continuous development of innovative Marxism which armed to achieve a comprehensive free development.

\section{B. Propagation Mode Selection of Marxist Youth}

In 1948, Lasswell clearly put forward the communication process and its five basic elements, namely: who said what, through what channels and to whom, and achieved what effect. This is the famous " $5 \mathrm{~W}$ " mode of transmission. Combined with the spread of Marxism youth issues, which are the five elements of the spread of Marxism young communication subject, communication content, communication channels, communication objects, and communication results.

\section{MARXIST YOUTH STRATEGY UNDER COMMUNICATION CONTEXT}

\section{A. Training Opinion Leaders - Communication Subject Popularization}

There is no doubt that training opinion leaders is one of the important ways for Marxism communication subject popularization. An opinion leader is an important role in the two-step flow of communication, which plays an important role in the formation of an intermediary or filtration process of the dissemination of results.

Longitudinal Perspective: the role of teachers' opinion leaders. The teacher is the student's faith pilot who is enlightenment, growth and development leaders for students. Teachers' beliefs have a strong positive guidance for students' beliefs.

Lateral Perspective: youth leaders' main communication role. Youth Leadership means that youth groups at the core and hub position to master and dominate the population of relationships and resources, to design and contribute, to achieve the organization's survival and development of group-wide resource owners, decision makers, driven and guardian. Youth leaders are the most active nongovernmental leadership of youth groups, the general trend of the development of young people have an important demonstration and "pre-figurative" effect in the process of Marxism.

\section{B. Grasp the Audience Features: Communication Object More Qualitative}

Youth development includes ideological and political quality, scientific and cultural qualities and health quality and other aspects. To achieve this comprehensive youth development, there must be material, spiritual and social support. Awareness and acceptance of Marxism is an important spiritual support for youth development. Contemporary youth's grasp of Marxism is inaccurate, acceptance and understanding is more dogmatic, especially lack of belief in the spirit of the pursuit of a comprehensive interpretation of the history and reality of Marxism, and may also be lack of contemporary youth.

Moral status mainstream of contemporary youth thinking is positive, healthy and progressive, but under the conditions of the socialist market economy and opening up all kinds of ideas and cultures clash, contemporary youth's ideological and moral independence, selection, complexity, variability, differences significantly enhanced, many young people affected by various ideologies and cultures increased significantly, mainly in: First, ideals and beliefs pragmatic, utilitarian increasing obvious. Second, weak sense of politics, political quality is not high. Deep-seated contradictions and social problems appears in the process of social transformation, objectively making youth growing up environment very complex, some people insist on the right, there are some one-sided political direction, blur and even wrong understanding, political acumen and discernment is 
not high. Third, values show diversity, volatility and contradiction. Life values of quite a few young people are varying degrees of utilitarian tendencies, some young people do not pay attention to personal development, national and collective interests unite for social responsibility and obligation, lack of awareness, lack of the spirit of hard work, poor organization and discipline, weak right-wrong value, lack of team spirit.

\section{Rich Communication Media-Communication Methods Diversification}

Marxism youth communication should be able at any time, in any way, in various cultural styles. Marxism of youth and youth of Marxism is inseparable from Marxism diversification of sources and communication channels.

Communication methods diversity is the inevitable result. In addition to the youth of the spread of Marxism in the traditional "big social class" and the "small school classroom", the mass media are an important mode of transmission. Schramm believes that in an era of social change, mass media, this change is not only those who speak and those who are contributing to this change. The mass media promote social behavior to the new customs, and even the transition to a new social relationship. "Media is a force of liberation, because they can break the barriers of distance and isolation, the people transferred from a traditional society to a 'Great Society' in." The mass media is the main channel for contemporary youth to accept the information, but also their willingness to accept mode of transmission. Mass media refers to the transmission of "useful to copy and disseminate information symbols machinery and editorial staff of newspapers, radio stations spread like intervening tissue distribution channels." In addition, the network has become an important position spread Marxism. Mass media to report the news bears, dissemination of information, entertainment, cultural heritage, education and supervision and many other features, the contemporary Chinese Marxism was able to achieve what the youth of many functions through the mass media. The first is the print media. There are newspapers, magazines and books, etc. These are the youth of the importance of Marxist propaganda media. The second is the electronic media. There are movies, radio and television. The third is the network media. The rapid development of the Internet, information technology, and digital communication environment for the youth of contemporary Chinese Marxism proposed new topics. Network not only brought modern means of education, but also brings a modern educational concepts and content to the contemporary Chinese Marxism youth.

\section{Unblocked Feedback - Controlled Communication Result}

Communication result is an effective result of communication behavior. On the Marxism youth, its spread effect is mainly reflected in three aspects: First, changes in the spread of the object, that is, young people accept the
Marxist theory of internalization and externalization situation; the second is the change propagation environment, namely the spread of Marxism impact of activities in the youth group generated overall atmosphere; the third is innovation theory itself, that Marxism in the young of their own development process improvement and innovation. Marxism is a dynamic process with the youth of the target state dual connotation of unity, is an extremely complex social engineering systems. According to scientific decision-making to ensure its correct pre-established goals and tasks orderly and coordinated operation, develop, and maintain the correct direction, you need to build flexible scientific regulatory mechanisms for timely dissemination process for regulation.

\section{CONCLUSION}

Feedback is the advice from those who pass information back to the communicator or destination or source, in order to help regulate the subsequent output information disseminators. Marxist youth feedback mechanisms is a target system refers to the youth Marxism communication as the criterion and basis of the youth situation presents its propagation compared and influence and change propagation process and the situation in a particular way, to ensure that along with the stated objectives of the internal consistency of the propagation path with a run, and to achieve the stated process objectives. Building a good Marxist youth feedback mechanisms, we must first get youth's feedback information, including youth Marxism communication subject, communication methods, feedback of communication contents and assessment of communication result. Second, we must obtain the evaluation of the information society. Evaluation content is contemporary Marxism for mastering and accepting of youth, mainly from two dimensions: quantity and quality to measure. Again from a theory of their own development goals and innovation trajectory propagation obtain feedback. Main assess whether the youth of the dissemination process of their own development logic of Marxism; whether changing realities and social problems are explained, leading the growth and development of young people; whether the level of innovation from the practice of the theoretical system of Marxism, promote the popularization of Marxism and younger.

\section{References:}

[1] Marx and Engels, Marx and Engels Selected Works (Volume 4) [M] Beijing: People's Publishing House, 1995.681.

[2] Gao Chaojie. On Marxism Reason Perish Holistic Thinking [J] Henan Institute of Science and Technology, 2012, (7): 39

[3] Liu Shulin. Boyi Popularity of Contemporary Chinese Marxism and Ideological and Political Work in the New Task [J] study of political and ideological work, 2008: (1): 27

[4] Li Chunhui. Marxism Popularity Dissemination of Research [D] perish, Northeast Normal University, Dr. Wen, 2011: 10, 19-20

[5] Willby - Schramm. Mass Media and Social Development [M] Beijing: China Press, 1990: 134 